\title{
EFFECT OF QUAIL LITTER BIOCHAR ON PRODUCTIVITY OF FOUR NEW PHYSIC NUT VARIETIES PLANTED IN CADMIUM-CONTAMINATED SOIL
}

\author{
Tawadchai Suppadit ${ }^{1 *}$, Viroj Kitikoon ${ }^{2}$, Anucha Phubphol ${ }^{3}$, and Penthip Neumnoi ${ }^{4}$
}

\begin{abstract}
Biochar can improve soil structure and water retention, enhance nutrient availability and retention, ameliorate acidity, and reduce heavy metal toxicity to plant roots. In this study, a basin experiment was conducted to investigate the effects of quail litter biochar (QLB) on the availability of Cd to physic nut (Jatropha curcas L.) plants. QLB was applied to the soil in which four new physic nut varieties (Takfa, Doi Saket, Lao, and Rayong) in factorial combinations at four levels $(0,5,10$, and 15 $\mathrm{g} \mathrm{kg}^{-1}$ soil) to soil that contained $60.8 \mathrm{mg} \mathrm{Cd} \mathrm{kg}^{-1}$. After transplanting plant height and canopy radius were measured every 2-mo and the number of leaves and branches at 6-mo, while yield components and Cd residues were measured at 8-mo intervals. The contaminated soil was analyzed for chemical characteristics, nutrients, and Cd residue after the plant harvest. The addition of QLB to soil caused a significant increase in the soil's growth potential and physic nut yield components $(\mathrm{P}<0.05)$, a significant decrease in the $\mathrm{Cd}$ residue in the plant $(\mathrm{P}<0.05)$, and a significant increase in the chemical characteristics, nutrients, and $\mathrm{Cd}$ residue in soil $(\mathrm{P}<0.05)$. In conclusion, QLB application can significantly decrease the bioavailability of $\mathrm{Cd}$ to physic nut plants, increase plant growth potential and yield, and has potential to remediate $\mathrm{Cd}$ contaminated soil. However, QLB levels higher than $15 \mathrm{~g} \mathrm{~kg}^{-1}$ soil mixture were not advisable because QLB is alkaline in nature, and this can affect soil $\mathrm{pH}$.
\end{abstract}

Key words: Adsorption, heavy metal, phytoremediation, plant production, pyrolysis, soil amendment.

$\mathrm{C}$ admium $(\mathrm{Cd})$ is a toxic heavy metal that is an environmental concern (Mahler et al., 1981). There are many sources of environmental Cd pollution, including fuel combustion, industrial sludges, phosphate fertilizers, and mine tailings (Unhalekhana and Kositanont, 2008). Cd can be absorbed by the human body through respiration and consumption, and $\mathrm{Cd}$ then accumulates in the liver and kidney, causing acute and chronic symptoms such as nausea, abdominal pain, diarrhea, kidney dysfunction, and osteomalacia (soft bones) (Simmons et al., 2005). The first and most important case study occurred in the Jinzu river basin, Toyama Prefecture, Japan, in 1950. Private mines had released contaminated wastewater into the river. The water, used by a local community and used to irrigate paddy fields, caused Itai-itai disease, which leads to kidney damage, and more than 100 lives were lost. Since then, studies have found that the $\mathrm{Cd}$

${ }^{1}$ National Institute of Development Administration, School of Social and Environmental Development, Bangkapi, Bangkok 10240, Thailand.

"Corresponding author (tawatc.s@nida.ac.th; stawadchai@yahoo.com). ${ }^{2}$ Mahidol University, Faculty of Tropical Medicine, Rajthevee, Bangkok 10400, Thailand.

${ }^{3}$ Mae Sot Farmer Group, Mae Sot District, Tak Province 63110, Thailand.

${ }^{4}$ Bureau of the Budget, Phaya Thai, Bangkok 10400, Thailand. Received: 5 July 2011.

Accepted: 26 December 2011. concentration around that riverbank is $4.85 \mathrm{mg} \mathrm{kg}^{-1}$ soil or approximately 14 times that of unaffected soil $(0.34 \mathrm{mg}$ $\mathrm{kg}^{-1}$ soil) (Unhalekhana and Kositanont, 2008).

In the Huay Maetao watershed, Mae Sot District, Tak Province, Thailand, $\mathrm{Cd}$ residues were found in the environment and in products such as rice, aquatic animals, and drinking water because of nearby mineral extraction activities (Wongsanoon, 2005). These activities included drilling, material transfer, and the removal of mine tailings and drainages (Chanthachot et al., 2005). Simmons et al. (2005) studied the Cd concentration in 154 soil samples collected in the Huay Maetao area and found Cd levels in rice field soils of $3.40-284 \mathrm{mg} \mathrm{kg}^{-1}$ soil, 94 times the European Economic Community's maximum permissible concentration in soil ( $3 \mathrm{mg} \mathrm{kg}^{-1}$ soil). This level of $\mathrm{Cd}$ residue has affected the health, livelihoods, and way of life of the farmers living in the area because their production is considered unfit for consumption (Unhalekhana and Kositanont, 2008). To address this problem, one promising approach for restricting Cd contamination in the soil and reducing $\mathrm{Cd}$ residues in agricultural products is through adsorption to biochar.

Biochar is a product of thermal decomposition of biomass produced by a process known as pyrolysis (heating in the absence of oxygen) (Chen et al., 2010). The microscopic physical structure of biochar is the key to its success in reducing heavy metal contamination (Suppadit, 
2009). Hossain et al. (2010) reported that biochar can induce an increase the heavy metal fraction of soil and decrease heavy metal uptake in soil. Biochar application reduced the extractability of heavy metals such as $\mathrm{Cd}$ from the soil. This significant change in the extractability and in the metal sequential fractions indicated that the available exchangeable form of heavy metals in soil can be transformed into an unexchangeable form (Qiu and Guo, 2010). A separate environmental issue in this area is the disposal of litter from quail farms. The litter can be a source of pathogens, and it can produce poisonous gases during fermentation (Suppadit, 2009). To address both of these issues, using pyrolysis to convert animal waste such as quail litter into biochar could reduce the environmental pollution from both of these sources.

Another significant problem in Thailand is a lack of energy; oil imports amount to more than US\$2.86 billion each year (Suppadit, 2003). Plants that can be used for renewable energy or biodiesel that can also be grown in highly Cd-contaminated areas could be an alternative solution to these problems. Physic nut (Jatropha curcas L.) is an alternative cash crop that can generate income for the grower. It can be used in oil production because its oil content is $34 \%$ and the extraction process is not complicated. The oil obtained can be used directly in an engine without mixing with fuel oil or going through a biodiesel production process. This results in reduced processing costs. Like diesel, physic nut is a highly efficient fuel (Thummaprasit, 2005). The physic nut grows rapidly and produces yields 8 -mo after seeding. The grower does not need to use extensive technology to grow it, and it is not part of the food chain (Cock et al., 2009; Jaime and Salazar, 2010). In addition, physic nut plants can be used to remove $\mathrm{Cd}$ from soil as a phytoremediation method (Mangkoedihardjo and Surahmaida, 2008).

Based on these reasons, the objectives of the present study were to investigate the effect of quail litter biochar (QLB) on soil quality and on the growth, productivity and safety of physic nut plants planted in a rice field soil in the Huay Maetao area, which has a high level of $\mathrm{Cd}$ contamination.

\section{MATERIALS AND METHODS}

\section{Experimental location and soil collection}

The experiment was conducted in the Mae Sot District, Tak Province, Thailand from May 2010 to May 2011. The experiment was performed under natural light and temperatures of $22.5 \pm 4{ }^{\circ} \mathrm{C}$ at night and $32.5 \pm 3.2^{\circ} \mathrm{C}$ during day in an open area that measured $20 \times 20 \mathrm{~m} \mathrm{(400}$ $\mathrm{m}^{2}$ ). Corrugated iron and blue netting were used as border around the experimental area. The concrete basins in which the physic nut plants were planted were $100 \mathrm{~cm}$ in diameter $\left(7857 \mathrm{~cm}^{2}\right) \times 30 \mathrm{~cm}$ high .

Approximately $10 \mathrm{t}$ of soil were collected and mixed from 15 sites within the Huay Maetao area $\left(170 \mathrm{~km}^{2}\right)$.
The soil was classified as part of the Tha Yang soil series (Loamy-skeletal, siliceous, isohyperthermic Kanhaplic Haplustults) (Land Development Department, 2011). This highly Cd-contaminated soil (> $60 \mathrm{mg} \mathrm{Cd} \mathrm{kg}^{-1}$ soil) was chosen to determine the effect of QLB treatments on physic nut growth and production. A composite sample of the upper $10 \mathrm{~cm}$ of soil was collected and then passed through a 6-mm sieve before mixing, analyzing, and planting according to the methods described by Hossain et al . (2010). The chemical characteristics, nutrients, and $\mathrm{Cd}$ levels in the soil before the experiment are presented in Table 1 .

\section{Biochar production}

The biochar used in this study was produced from quail litter. Quail litter was randomly chosen from farms located in Singburi Province, Thailand. QLB was produced using a $500{ }^{\circ} \mathrm{C}$ pyrolysis temperature as recommended by Lehmann (2007). The quail litter was packed into a ceramic container, covered with a lid and combusted in a muffle furnace (K-SF05, Humanlab, K\&K Scientific Supplier, Seoul, South Korea) at $500{ }^{\circ} \mathrm{C}$ for $5 \mathrm{~h}$ to generate biochar according to the methods of Uzoma et al. (2011). After pyrolysis, the QLB was ground through a $1 \mathrm{~mm}$ sieve to ensure the biochar would have the same particle size as the soil used in the experiment. The chemical characteristics, nutrients, and Cd levels in the QLB are presented in Table 1.

\section{Experimental design}

Physic nut plants were collected from a local agricultural agency and were bred by the Chiang Mai Field Crops Research Center in January 2003. The physic nut variety and the quantity of the QLB were assessed in a $4 \times 4$ factorial arrangement with four replicates in a completely randomized design (Johnson and Bhattacharyya, 2001).

Table 1. Chemical characteristics of soil and quail litter biochar (QLB) used in a basin experiment.

\begin{tabular}{lcc}
\hline Characteristics & Soil & QLB \\
\hline $\mathrm{EC}, \mathrm{dS} \mathrm{m}{ }^{-1}$ & 0.140 & 2.20 \\
$\mathrm{pH}$ & 6.90 & 9.10 \\
Exchangeable cations & & \\
$\mathrm{CEC}, \mathrm{cmol} \mathrm{kg}^{-1}$ & 0.980 & 6.35 \\
$\mathrm{~K}, \mathrm{cmol} \mathrm{kg}^{-1}$ & 0.230 & 0.280 \\
$\mathrm{Ca}, \mathrm{cmol} \mathrm{kg}^{-1}$ & 0.455 & 2.34 \\
$\mathrm{Mg}, \mathrm{cmol} \mathrm{kg}^{-1}$ & 0.192 & 1.52 \\
Elements & & \\
$\mathrm{C}, \mathrm{mg} \mathrm{kg}^{-1}$ & 310 & 32800 \\
$\mathrm{Total} \mathrm{N}, \mathrm{mg} \mathrm{kg}^{-1}$ & 208 & 1620 \\
$\mathrm{C} / \mathrm{N} \mathrm{ratio}$ & 6.30 & 20.2 \\
$\mathrm{P}, \mathrm{mg} \mathrm{kg}^{-1}$ & 604 & 9620 \\
$\mathrm{~K}, \mathrm{mg} \mathrm{kg}^{-1}$ & 723 & 6750 \\
$\mathrm{Ca}, \mathrm{mg} \mathrm{kg}^{-1}$ & 1048 & 10050 \\
$\mathrm{Mg}, \mathrm{mg} \mathrm{kg}^{-1}$ & 334 & 020 \\
$\mathrm{Fe}, \mathrm{mg} \mathrm{kg}^{-1}$ & 4.36 & 910 \\
$\mathrm{Zn}, \mathrm{mg} \mathrm{kg}^{-1}$ & 0.460 & 182 \\
$\mathrm{Cu}, \mathrm{mg} \mathrm{kg}^{-1}$ & 0.910 & 143 \\
$\mathrm{Mn}, \mathrm{mg} \mathrm{kg}^{-1}$ & 13.9 & 342 \\
$\mathrm{Heavy} \mathrm{metal}$ & & \\
$\mathrm{Cd}, \mathrm{mg} \mathrm{kg}^{-1}$ & 60.8 & 14.8 \\
\hline
\end{tabular}

EC: electrical conductivity; CEC: cation-exchange capacity. 
The first factor was the physic nut varieties Takfa (var. Tak.), Doi Saket (var. Doi), Lao (var. Lao), and Rayong (var. Ray.), and the second factor as the QLB levels at 0 (QLB0), 5 (QLB5), 10 (QLB10), and 15 (QLB15) $\mathrm{g} \mathrm{kg}^{-1}$ soil. The amount of biochar applied to $\mathrm{Cd}$-contaminated soil was based on previous investigations by Namgay et al. (2010). Each basin received $150 \mathrm{~kg}$ of air-dried soil, which was then mixed with the various QLB treatments.

\section{Planting and data collection}

Physic nut seeds of each variety were planted in individual plastic pots. Three-month-old seedlings were transplanted into the trial concrete basin, with 1 plant basin ${ }^{-1}$. These were watered every week and weeded by hand. An aqueous solution of tobacco leaves was used for insect control. Soil temperature, moisture, and $\mathrm{pH}$ were measured every week, plant height and canopy every 2 -mo, and number of leaves and branches at 6 -mo after transplanting. The yield components included the number of fruits per plant, the fresh and dry fruits weights of each plant, the fresh and dry fruit weight per fruit, the number of seeds per fruit, and the weight of 100 dry seeds and were measured at 8-mo after transplanting. The oil at harvest was obtained using a screw press.

\section{Laboratory analyses}

At the end of the basin experiment, the plant and its seeds and oil, the QLB, and the soil samples were sent to laboratories at the Chiang Mai Field Crops Research Center and Kasetsart University. The soil from each basin was air-dried at $36{ }^{\circ} \mathrm{C}$ to constant weight and passed through a 4-mm sieve to separate out the plant debris. The plants and seeds were oven-dried at $70{ }^{\circ} \mathrm{C}$ to constant weight before weighing to determine the DM, oil, and $\mathrm{Cd}$ content. The $\mathrm{Cd}$ residue in plant component tissues was measured using direct aspiration with an atomic absorption spectrophotometer (AAS; Analytik JenaNVAA 300, Analytica, Jena, Germany) according to the procedures of Tessier et al. (1979). Cd and nutrients in the QLB and soil were measured using an inductively coupled plasma emission spectrophotometer (ICPES; ACTIVA-M, Horiba Jobin Yvon, Tramoyes, France) according to the procedures of AOAC (1970; 1980). QLB and soil chemical characteristics were analyzed for EC (electrical conductivity meter; Amber Science 4083, Amber Science, Oregon, USA), $\mathrm{pH}$ ( $\mathrm{pH}$ meter; Sension 156, HACH, Colorado, USA), moisture (Tensiometer; BP100, KRUSS, Hamburg, Germany), and organic matter (OM) (Walkley-Black method), based on procedures from the Land Development Department (2004) manual. CEC was estimated using an $\mathrm{NH}_{4}{ }^{+}$-replacement method according to procedures of Schollenberger and Simon (1945), and leachates were analyzed for exchangeable cations $\mathrm{K}, \mathrm{Ca}$, and $\mathrm{Mg}$ according to procedures described by Uzoma et al. (2011).

\section{Statistical analyses}

Data were analyzed using ANOVA. When significant differences were found, the least significant difference (LSD) test of the Statistical Analysis System (SAS version 6.12) was used to test for interactions and differences among the treatment means at a significance level of $P<0.05$ (SAS Institute, 1996).

\section{RESULTS AND DISCUSSION}

\section{Growth potential and yields}

There were no interactions between the physic nut variety and the QLB level factors in terms of the total growth potential or any of the yield components. Plant height (Figure 1a), canopy radius (Figure 1b), number of leaves (Figure 1c), and number of branches (Figure 1d) at the initial stage of the experiment were not significantly different among the four varieties $(\mathrm{P}>0.05)$. Measurements taken 2, 4, 6, and 8-mo after transplanting showed that there were still no statistically significant differences in plant height or canopy among the four varieties $(\mathrm{P}>0.05)$. Similar to the measurements taken at 6-mo, there were no differences in the number of leaves or the number of branches among four varieties $(\mathrm{P}>$ $0.05)$. Yield components were assessed in terms of the number of fruits per plant, fresh fruit weight per plant, dry fruit weight per plant, fresh fruit weight per fruit, dry fruit weight per fruit, number of seeds per fruit, dry weight of 100 seeds, and percentage of oil per seed weight (Table 2). At the end of the 8-mo experiment, there were no significant differences among physic nut varieties $(P>0.05)$. However, all varieties of physic nut plants planted in Cd-contaminated soil without QLB showed a lower in growth potential and lower yield components than in the other treatments $(\mathrm{P}<0.05)$, likely because $60.8 \mathrm{mg} \mathrm{Cd} \mathrm{kg}^{-1}$ soil has an adverse effect on plants by affecting metabolic processes, photosynthesis, and respiration (Mahler et al., 1981), leading to slower growth than in physic nut plants planted in normal soil (Suppadit et al., 2008). Francis (1994) reported that Cd at 1-10 $\mathrm{mg} \mathrm{kg}^{-1}$ could affect the growth potential of lettuce. Similarly, Sanoh (2005) found that growth potential of vetiver grass, sunflower, and rice decreased with increasing Cd levels, stunting their growth. Chehregani and Behrouz (2007) and Mangkoedihardjo and Surahmaida (2008) reported that physic nut plants grew normally when the level of $\mathrm{Cd}$ residue was $<50 \mathrm{mg} \mathrm{kg}^{-1}$.

There was a significant $(P<0.05)$ increase in the growth potential and yields of the all physic nut varieties with increasing soil QLB level. The application of QLB in Cd-contaminated soil increased the growth and yield of physic nut plants compared to the non-QLB treatments, likely because QLB was both a soil fertilizer and a soil amendment. The QLB increased nutrient availability, particularly of N (Schmidt and Noack, 2000). The QLB was not easily degraded by soil microbes, which favored 
(a)

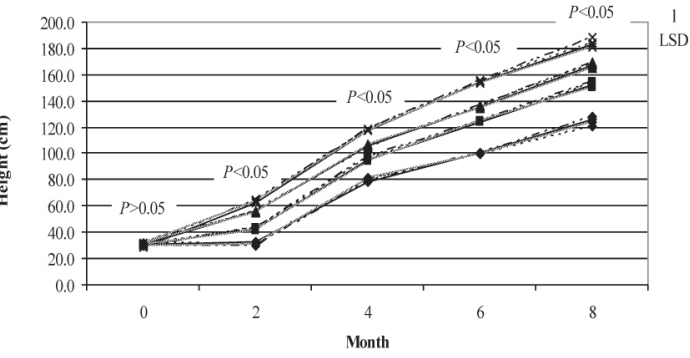

(c)

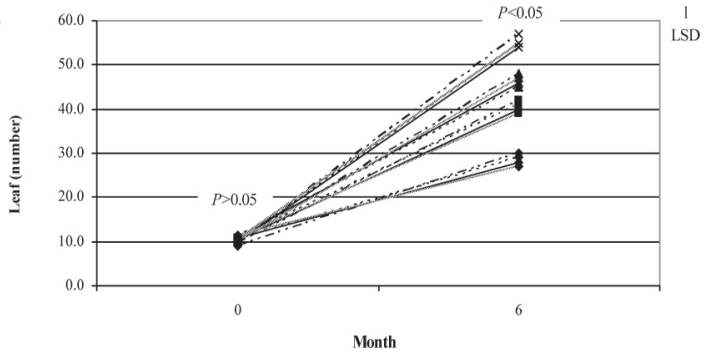

(b)

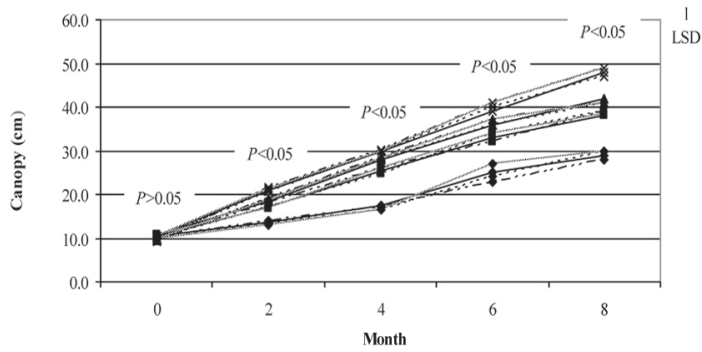

(d)

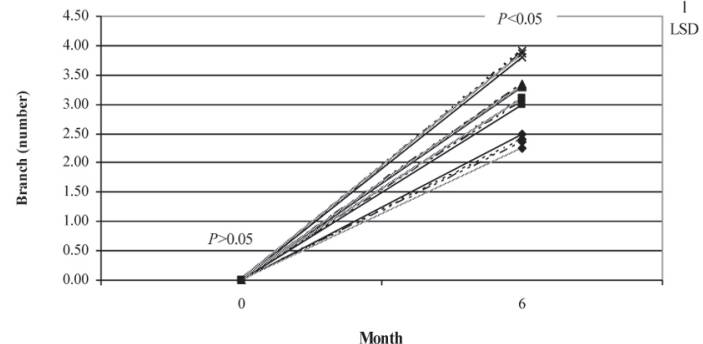

\begin{tabular}{|c|c|c|c|}
\hline - — Var. Tak. QLB0 & — Var. Tak. QLB5 & — Var. Tak. QLB10 & ※ Var. Tak, QLB15 \\
\hline$\bullet$ & $\cdots \cdot \cdots \mathrm{Va}$ & $\cdots$ « V Var. Doi. QLB10 & 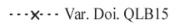 \\
\hline$-\cdot \leftarrow \cdot$ Var. Lao. & -•-・Var. Lao. QLB5 & - - Var. Lao. QLB10 & $-\cdot x-\cdot$ Var. Lao. QLB15 \\
\hline - Var. Ray. QLB0 & - Var. Ray. QLB5 & $\_\quad$ Var. Ray. QLB10 & × Var. Ray. QLB15 \\
\hline
\end{tabular}

Figure 1. Plant height (a), canopy (radius) (b), number of leaves (c), and number of branches (d) of four physic nut varieties planted in Cd-contaminated soil treated with quail litter biochar $(\mathrm{QLB})$ at various levels. Vertical lines represent LSD at $P=0.05$.

the incorporation of this material into the soils (Glaser $e t$ $a l ., 2002)$. Because QLB is a porous material with a high surface area (Liang et al., 2006), it could be affected by soil moisture and nutrient dynamics (Uzoma et al., 2011). These results imply that the addition of QLB to soil allowed percolating soil moisture more residence time within the root zone, thereby making the soil moisture and nutrients more available to growing physic nut and eventually improving crop productivity (Steinbeiss et al., 2009). In addition, the increase in physic nut growth and yield was mainly due to the improvement in soil CEC and the increased nutrient content of the soil (Hossain et al., 2010). However, these results should be interpreted with caution; the soil $\mathrm{pH}$ increased with increasing QLB mixture because QLB is alkaline (Suppadit, 2009). The optimum soil $\mathrm{pH}$ for physic nut production is 6.5-7.5 (Suppadit et al., 2008).

\section{Cd residue in plant}

There was no interaction between physic nut variety and QLB level in terms of the amount of Cd residue in plants. There were no differences in the amount of $\mathrm{Cd}$ residues in the stem, root, leaves, seed, oil, or seed meal $(\mathrm{P}>0.05)$ among physic nut varieties (Table 2). This finding indicates that all physic nut varieties were able to absorb $\mathrm{Cd}$ from the soil at nearly the same rate. The Cd levels in tissues of plants grown in Cd-contaminated soil without QLB treatments were higher than legal limits of $0.1-2.0 \mathrm{mg} \mathrm{kg}^{-1}$ (Pollution Control Department, 2006), except for seed meal. Phytoextraction, through convection and diffusion, leads to the accumulation of $\mathrm{Cd}$ in the plants (Crowley et al., 1991). Cd ions dissolved in water move from soil solids at the rhizosphere to the root (Panichasakpatana, 1996). The water is absorbed by the root to replace water used in respiration (Romheld and Marschner, 1986). $\mathrm{Cd}$ accumulates in roots more than in stems and leaves because roots have more opportunities to come into contact with $\mathrm{Cd}$ and have longer $\mathrm{Cd}$ accumulation times than stems or leaves (Suppadit et al., 2008). These results are in agreement with a study by Giesy et al. (1981), who found the highest $\mathrm{Cd}$ levels in root tissues, followed by stems and then the leaves of mangrove plants. Meanwhile, all varieties of physic nut had a significantly $(\mathrm{P}<0.05)$ lower level of $\mathrm{Cd}$ residue in all plant tissues when there was a higher level of QLB in the soil. The results clearly show the ability of QLB to immobilize a mixture of $\mathrm{Cd}$ in soil. In fact, the bio-available fraction of heavy metals is reduced in the presence of biochar (Uchimiya et al., 2010). The strong binding of $\mathrm{Cd}$ to the surface functional group of biochar makes it less available to the plants (Namgay et al., 2010). Hossain et al. (2010) reported that biochar can increase the heavy metal fraction of soils and decrease the uptake of heavy metals. Biochar application reduces the extractability of heavy metals in soil and causes significant changes in the extractability and metal sequential fractions, indicating that the available form of heavy metals in soil can be transformed into unexchangeable forms (Qiu and Guo, 2010). Cao and $\mathrm{Ma}$ (2004) found that addition of biochar decreased $\mathrm{Cd}$ accumulation in carrots and lettuce. Therefore, QLB can 


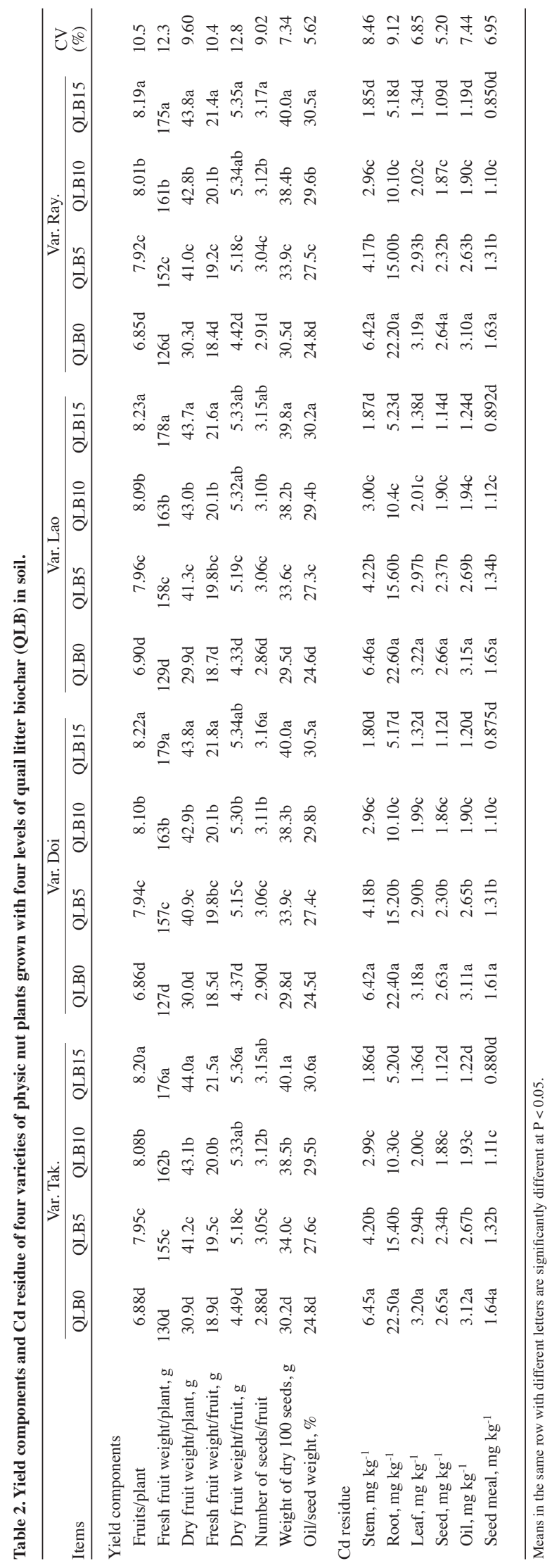

significantly affect heavy metal absorption (Uchimiya et al., 2010), acting as a barrier against the negative characteristics of heavy metal contamination (Kookana, 2010) and mitigating the adverse influence of heavy metals on plant growth and yield (Chen et al., 2010).

\section{Chemical characteristics, nutrients, and Cd residue in soil}

There were no interactions between physic nut variety and QLB level factors for total chemical characteristics, nutrients, or amount of $\mathrm{Cd}$ residue in soil. Although there were no changes in $\mathrm{pH}$ or $\mathrm{C} / \mathrm{N}$ ratio, $\mathrm{Cd}$-contaminated soil without QLB showed a decrease in EC, exchangeable cations, soil nutrients, and $\mathrm{Cd}$, when compared to the levels in the soil before the experiment (Table 3). This may be because these substances were absorbed by the plants as well as leached by watering and rainfall (Suppadit, 2005). In addition, there were no significant differences $(\mathrm{P}>0.05)$ in the levels of EC, $\mathrm{pH}$, exchangeable cations, soil nutrients, and heavy metal among the four varieties of physic nut. This finding implies that soil nutrients and $\mathrm{Cd}$ were absorbed at almost the same rate by each variety. There was a significant $(\mathrm{P}<0.05)$ increase in the $\mathrm{EC}, \mathrm{pH}$, exchangeable cations, and soil nutrients of all varieties when there was an increase in the soil QLB level. QLB may have the ability to increase the mineralization of soil organic $\mathrm{N}$ upon its incorporation into soil because of its priming effect (Hamer et al., 2004) and its high C content (Singh et al., 2010). However, increasing the amount of QLB increased the soil C more than the soil N. This was reflected in the significant increase in the $\mathrm{C}: \mathrm{N}$ ratio with increasing amounts of QLB. After adding QLB, the more optimal $\mathrm{C}: \mathrm{N}$ ratio promoted mineralization of $\mathrm{C}$ compounds by enhancing the growth of microorganisms and releasing the available N. Exchangeable nutrients (K, $\mathrm{Ca}$, and $\mathrm{Mg}$ ) and cation-exchange capacity (CEC) in postharvest soils were higher in the treatments in which more QLB was applied. QLB improved the exchangeable cation status and CEC and increased the nutrient availability of the soil (Chan et al., 2008). The formation of surface functional groups and adsorption sites on biochar can influence its CEC (Cheng et al., 2006; Liang et al., 2006). The increase in $\mathrm{pH}$ caused by biochar application may also have enhanced the adsorption of $\mathrm{Cd}$ to biochar (Namgay et al., 2010). The development of carboxylic-C and aromatic-OH functional groups on biochar surfaces during their oxidation (Liang et al., 2006) could also have increased the CEC of the soil (Cheng et al., 2006) and possibly increased the Cd-exchange capacity of the soil (Namgay et al., 2010). The adsorption and retention capacity for nutrient ions, such as $\mathrm{K}, \mathrm{Ca}$, and $\mathrm{Mg}$ released from fertilizer, the maintenance of an adequate water supply and a slow release of nutrients might also have caused these increases (Eshghi et al., 2010). Asai et al. (2009) also reported an increase in plant productivity after biochar application, and they attributed this increase 


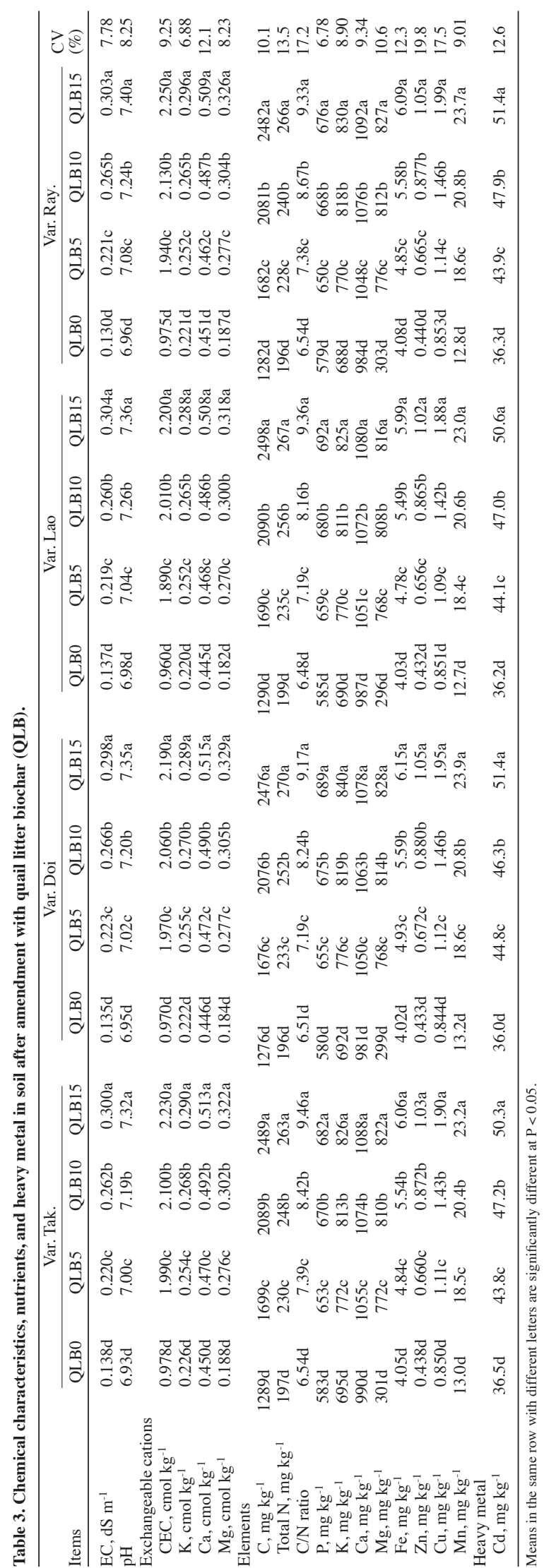

to the increase in available soil nutrients. Therefore, the increased physic nut growth and yield might be due to the greater availability of nutrients from the soil. At the same time, an increase in the level of remaining $\mathrm{Cd}$ in soil was observed and corresponded to an increased level of QLB. QLB is alkaline in nature (Suppadit, 2009) and Cd in more alkaline soil moves slowly and shows less leaching after watering or rainfall (Panichasakpatana, 1996). In addition, QLB can significantly decrease due to the heavy metal absorption by plant (Uchimiya et al., 2010).

\section{CONCLUSIONS}

These results highlight the potential benefits of QLB application for remediating Cd-contaminated soils, which are widespread in the Huay Maetao watershed. The QLB has a positive effect on soil quality and lays a foundation for the improved growth and yield of the four new physic nut varieties. The addition of QLB allowed the percolating soil moisture to have a longer residence time within the root zone, thereby making soil moisture and nutrients more available to the growing physic nut plants and eventually improving crop productivity. The QLB had the potential to decrease the availability of $\mathrm{Cd}$ to physic nut plants. The concentration of $\mathrm{Cd}$ in physic nut components decreased with increasing application of QLB to the soil. Therefore, the results from this study can be used to predict the efficiency of QLB application when it is used to remediate Cd-contaminated soil. However, more than $15 \mathrm{~g} \mathrm{QLB} \mathrm{kg}^{-1}$ soil mixture should not be used because soil $\mathrm{pH}$ was raised above the requirements for physic nut plants. There is a need for additional field experiments to evaluate long-term benefits of QLB addition at various application rates including its potential to reduce the bioavailability of toxic trace elements in $\mathrm{Cd}$ contaminated soils.

\section{ACKNOWLEDGEMENTS}

The authors would like to thank the Marshucon Public Company Limited for the muffle furnace and would like to express their deepest appreciation to the Chiang Mai Field Crops Research Center and Kasetsart University for their permission to use some of their laboratory facilities.

Efecto del biocarbón de cama de codorniz en la productividad de cuatro variedades nuevas de jatrofa plantadas en suelo contaminado con cadmio. Se ha visto que el biocarbón mejora la estructura del suelo y la retención de agua, mejora la disponibilidad y la retención de nutrientes, controla la acidez y reduce la toxicidad de metales pesados en las raíces de las plantas. En este trabajo se investiga el uso de biocarbón de cama de codorniz (QLB) en la disponibilidad de Cd para la planta de jatrofa (Jatropha curcas L.) en un estudio de laboratorio. Se realiza una combinación factorial con 
cuatro variedades nuevas de jatrofa (Takfa, Doi Saket, Lao y Rayong) sobre cuatro proporciones de QLB a 0,5, 10 , y $15 \mathrm{~g} \mathrm{~kg}^{-1}$ añadidos por separado a suelo contaminado con $60,8 \mathrm{mg} \mathrm{Cd} \mathrm{kg}^{-1}$. Tras el trasplante se midió la altura de la planta y la cubierta vegetal cada 2 meses, el número de hojas y ramas a los 6 meses y los parámetros de rendimiento así como el residuo de $\mathrm{Cd}$ a los 8 meses. A continuación, tras la cosecha de la planta, se analizaron las características químicas, nutrientes y residuo de Cd en el suelo contaminado. El uso de QLB causó un aumento significativo en el potencial de crecimiento y en los parámetros de rendimiento $(\mathrm{P}<0,05)$, así como una disminución significativa del residuo de cadmio en las plantas $(\mathrm{P}<0,05)$ y una mejora significativa en las características químicas, nivel de nutrientes y residuo de $\mathrm{Cd}$ en el suelo $(\mathrm{P}<0,05)$. Se concluye que el uso de QLB puede disminuir significativamente la biodisponibilidad de Cd para la jatrofa, incrementar su potencial de crecimiento y rendimiento, y tiene el potencial de remediar el suelo contaminado con $\mathrm{Cd}$. No obstante, no se aconseja el uso de QLB por encima de $15 \mathrm{~g} \mathrm{~kg}^{-1}$ de suelo. Dado que el QLB es de naturaleza alcalina puede afectar al pH del suelo.

Palabras clave: Adsorción, metales pesados, fitorremediación, producción de plantas, pirólisis, enmienda de suelos.

\section{LITERATURE CITED}

AOAC. 1970. Official methods of analysis. 1015 p. $11^{\text {th }}$ ed. Association of Official Analytical Chemists (AOAC), Washington, D.C., USA.

AOAC. 1980. Official methods of analysis. 1018 p. $13^{\text {th }}$ ed. Association of Official Analytical Chemists (AOAC), Washington, D.C., USA.

Asai, H., B.K. Samson, H.M. Stephan, K. Songyikhangsuthor, K. Homma, Y. Kiyono, et al. 2009. Biochar amendment techniques for upland rice production in Northern Laos. 1. Soil physical properties, leaf SPAD and grain yield. Field Crop Research 111:81-84.

Cao, X., and L. Ma. 2004. Effects of compost and phosphate on plant arsenic accumulation from soils near pressure-treated wood. Environmental Pollution 132:435-442.

Chan, K.Y., L. Van Zwieten, I. Meszaros, A. Downie, and S. Joseph. 2008. Using poultry litter biochars as soil amendments. Soil Research 46:437-444.

Chanthachot, W., A. Busamongkol, S. Khuntong, R. Peripart, and S. Loaharojanapanal. 2005. Analysis of heavy metals in soil along Maetao river, Tak province by nuclear technique. p. 1-3. In Congress on Science and Technology, Thailand. 18-20 October 2005. Suranaree University of Technology, Nakhon Ratchasima, Thailand.

Chehregani, A., and E.M. Behrouz. 2007. Removal of heavy metals by native accumulator plants. International Journal of Agriculture \& Biology 9:462-465.

Chen, Y., Y. Shinogi, and M. Taira. 2010. Influence of biochar use on sugarcane growth, soil parameters, and groundwater quality. Soil Research 48:526-530.

Cheng, C.H., J. Lehmann, J.E. Thies, S.D. Burton, and M.H. Engelhard. 2006. Oxidation of black carbon by biotic and abiotic processes. Organic Geochemistry 37:1477-1488.
Cock, L.S., A.M.Z. Arenas, and A.A. Aponte. 2009. Use of enzymatic biosensors as quality indices: A synopsis of present and future trends in the food industry. Chilean Journal of Agricultural Research 69:270-280.

Crowley, D.E., Y.C. Wang, C.P.P. Reid, and P.J. Szaniszlo. 1991. Mechanisms of iron acquisition from siderophores by microorganisms and plants. Plant and Soil 130:179-198.

Eshghi, S., M.R. Mahmoodabadi, G.R. Abdi, and B. Jamali. 2010. Zeolite ameliorates the adverse effect of cadmium contamination on growth and nodulation of soybean plant (Glycine max L.) Journal of Biological \& Environmental Science 4:43-50.

Francis, B.M. 1994. Toxic substances in the environment. 360 p. John Wiley \& Sons Inc., New York, USA.

Giesy, J.P., J.W. Bowling, H.J. Kania, R.L. Knight, and S. Mashburn. 1981. Fates of cadmium introduced into a channel microcosm. Environment International 5:159-175.

Glaser, B., J. Lehmann, and W. Zech. 2002. Ameliorating physical and chemical properties of highly weathered soils in the tropics with charcoal - a review. Biology and Fertility of Soils 35:219230.

Hamer, U., B. Marschner, S. Brodowski, and W. Amelung. 2004. Interactive priming of black carbon and glucose mineralization. Organic Geochemistry 35:823-830.

Hossain, M.K., V. Strezov, K. Yin Chan, and P.F. Nelson. 2010. Agronomic properties of wastewater sludge biochar and bioavailability of metals in production of cherry tomato (Lycopersicon esculentum). Chemosphere 78:1167-1171.

Jaime, M.M., and C.A. Salazar. 2010. Participation in organizations, technical efficiency and territorial differences: a study of small wheat farmers in Chile. Chilean Journal of Agricultural Research 71:104-113

Johnson, R.A., and G.K. Bhattacharyya. 2001. Statistics principles and methods. 236 p. $4^{\text {th }}$ ed. John Wiley \& Sons Inc., New York, USA.

Kookana, R.S. 2010. The role of biochar in modifying the environmental fate, bioavailability, and efficacy of pesticides in soils: a review. Soil Research 48:627-637.

Land Development Department. 2004. Plant, fertilizer, water and soil analysis manual. 184 p. Ministry of Agriculture and Cooperatives, Bangkok, Thailand.

Land Development Department. 2011. Tha Yang series: Ty. 3 p. Ministry of Agriculture and Cooperatives, Bangkok, Thailand.

Lehmann, J. 2007. Carbon sequestration in dryland ecosystems. Environment Management 33:528-544.

Liang, B., J. Lehmann, and D. Solomon. 2006. Black carbon increases cation exchange capacity in soils. Soil Science Society of America Journal 70:1719-1730.

Mahler, R.J., F.T. Bingham, and A.C. Chang. 1981. Effect of heavy metal pollution on plants. Applied Science 1:72-109.

Mangkoedihardjo, S., and A. Surahmaida. 2008. Jatropha curcas L. for phytoremediation of lead and cadmium polluted soil. World Applied Sciences Journal 4:519-522.

Namgay, T., B. Singh, and B.P. Singh. 2010. Plant availability of arsenic and cadmium as influenced by biochar application to soil. p. 78-81. World Congress of Soil Science, Soil Solutions for a Changing World, Brisbane, Australia. 1-6 August 2010. International Union of Soil Sciences (IUSS), Wisconsin, USA.

Panichasakpatana, S. 1996. Soil pollution from chemical compounds application. 327 p. Kasetsart University, Bangkok, Thailand.

Pollution Control Department. 2006. Cadmium contamination in Huay Maetao watershed. 120 p. Ministry of Natural Resources and Environment, Bangkok, Thailand.

Qiu, G., and M. Guo. 2010. Quality of poultry litter-derived granular activated carbon. Bioresource Technology 101:379-386.

Romheld, V., and H. Marschner. 1986. Evidence for a specific uptake system for iron phytosiderophores in roots of grasses. Plant Physiology 80:175-180.

Sanoh, S. 2005. Uptake of heavy metals by vetiver grass, sunflower and rice from zinc, cadmium and lead contaminated soil. $132 \mathrm{p}$. Kasetsart University, Bangkok, Thailand. 
SAS Institute. 1996. SAS user's guide: statistics. 956 p. $4^{\text {th }}$ ed. SAS Institute, Cary, North Carolina, USA.

Schmidt, M.W.I., and A.G. Noack. 2000. Black carbon in soils and sediments: analysis, distribution, implications, and current challenges. Global Biogeochemical Cycles 14:777-793.

Schollenberger, C.J., and R.H. Simon. 1945. Determination of exchange capacity and exchangeable bases in soil-ammonium acetate method. Soil Science 59:13-24.

Simmons, R.W., P. Pongsakul, and D. Saiyasitpanich. 2005. Elevated levels of cadmium and zinc in paddy soils and elevated levels of cadmium in rice grain downstream of zinc mineralized area in Thailand: implications for public health. Environmental Geochemistry and Health 27:501-511.

Singh, B.P., B.J. Hatton, B. Singh, A.L. Cowie, and A. Kathuria. 2010. Influence of biochars on nitrous oxide emission and nitrogen leaching from two contrasting soils. Journal of Environmental Quality 39:1224-1235.

Steinbeiss, S., G. Gleixner, and M. Antonietti. 2009. Effect of biochar amendment on soil carbon balance and soil microbial activity. Soil Biology and Biochemistry 41:1301-1310.

Suppadit, T. 2003. Environmental health management. 240 p. The Graduate School of Social and Environmental Development, National Institute of Development Administration, Bangkok, Thailand.

Suppadit, T. 2005. Environment, ecology and management. 790 p. $2^{\text {nd }}$ ed. Banpim-Karnpim Press, Bangkok, Thailand.
Suppadit, T. 2009. Pollution from animal excreta on environmental health. 818 p. $3^{\text {rd }}$ ed. Tippanate Printing Press, Bangkok, Thailand

Suppadit, T., V. Kitikoon, and P. Suwannachote. 2008. Effect of cadmium on growth of four new physic nut (Jatropha curcas Linn.) varieties. Journal of ISSAAS 14:88-98.

Tessier, A., P.G.C. Campbell, and M. Bisson. 1979. Sequential extraction procedure for the speciation of particulate trace metals. Analytical Chemistry 51:844-851.

Thummaprasit, W. 2005. Physic nut. 48 p. The Graduate School of Social and Environmental Development, National Institute of Development Administration, Bangkok, Thailand.

Uchimiya, M., I.M. Lima, K.T. Klasson, S. Chang, L.H. Wartelle, and J. Rodgers. 2010. Immobilization of heavy metal ions $(\mathrm{Cu}$ ", $\mathrm{Cd}$ ", $\mathrm{Ni}$, and $\mathrm{Pb}$ ") by broiler litter-derived biochars in water and soil. Journal of Agricultural and Food Chemistry 58:5538-5544.

Unhalekhana, U., and C. Kositanont. 2008. Distribution of cadmium in soil around zinc mining area. Thai Journal of Toxicology 23:170-174.

Uzoma, K.C., M. Inoue, H. Andry, H. Fujimaki, A. Zahoor, and E. Nishihara. 2011. Effect of cow manure biochar on maize productivity under sandy soil condition. Soil Use Management doi:10.1111/j.1475-2743.2011.00340.x.

Wongsanoon, J. 2005. Cadmium contamination in Mae Tao stream in Amphur Mae Sod, Tak province. 118 p. The Graduate School of Social and Environmental Development, National Institute of Development Administration, Bangkok, Thailand. 